\title{
Effectiveness of Health Education of Families against the Management of Diabetes Mellitus in the Region of Kalumata Health Centre, City of Ternate
}

\author{
Arsad Suni ${ }^{1}$, Fatimah M. Saleh ${ }^{2}$ \\ ${ }^{1}$ School of Nursing, Health Polytechnic of Ternate, City of Ternate, North of Maluku, Indonesia \\ ${ }^{2}$ School of Nursing, Health Polytechnic of Ternate, City of Ternate, North of Maluku, Indonesia
}

\begin{abstract}
The prevalence of Diabetes Mellitus annually increasing that supposedly related to lifestyle changes (diet) along with increased prosperity and no longer limited to degenerative disease. This research aims to look at the effectiveness of family health education towards the management of diabetes mellitus. Design research using a Longitudinal Prospective "pre and posttest control group design using the approach of nonprobability sampling method of purposive sampling with the total sampling of as many as 30 respondents and conducted a test of regression linear value of significance $p=0.05$. Results of the study showed there was no effective health education family against management of patients of diabetes mellitus health education prior to the value of Standard Coefficients Beta 0236, the value of $t, 1,284$ Regression $p$ value 0410, there are family health education effectiveness against the management of diabetes mellitus patients after health education with the value of the Standard Beta Coefficients 0236, value $t$ 1,284, Regression $p$ value 0000. This means that there is a difference in the effectiveness of health education of patient management against family with diabetes mellitus before and after giving health education program with value Regression p value $=0000$.
\end{abstract}

Keywords: Family, Education, Health and management, Diabetes mellitus

\section{Introduction}

Diabetes mellitus (DM) is one of the disease is not infectious has been a health problem in the world. The incidence of this disease and prevalence is on the rise especially in the developing countries and of countries that have entered the cultural industrialization. Current DM is one of the chronic diseases that need serious handling. The International Diabetes Federation (IDF) mentioned in the year 2013 there are 382 million people in the world who suffer from DM, of which there are 175 million that has not been undiagnosed. It is expected to be increased to 592 million people will suffer from diabetes mellitus in the year 2035. The increase in the prevalence of DM in some developing countries are affected by the increased prosperity, increased per-capita income, and lifestyle changes especially in the big cities ( IDF, 2014; quoted by Image Windani Hartiah Sari, Mambang Haroen, Nursiswati, 2016).

The prevalence of DM in Southeast Asia by the year 2014 is $8.3 \%$, with no case terd of $52.8 \%$. Deaths from DM in sufferers aged less than 60 years of age was $53.8 \%$. The International Diabetes Federation (IDF) predicts the year 2035 the prevalence of DM in Southeast Asia increased to $10.1 \%$. In Indonesia in the year 2013, there are about 12 million people experienced DM, of which only 3 million undiagnosed (Maintenance Kemenkes RI, 2014). In the year 2030 estimated epidemiological prevalence of DM in Indonesia reached 21.3 million people. The results of the Basic Health Research (Riskesdas) in the year 2013, States in the proportion of the population of $\geq 15$ years with $\mathrm{DM}$ is $6.9 \%$, with impaired glucose tolerance (TGT) reached 29.9\%. This means it will be more and more of the population is at high risk for suffering a DM (Novelia Wulan Sofiana, Nurchayati, from the Oswati Hasanah, 2014).
Increasing the prevalence of DM in Indonesia, is no longer limited to degenerative diseases, allegedly has something to do with lifestyle (diet) along with rising prosperity. Diet shifts from a traditional diet that contains plenty of carbohydrates, fiber and vegetables to Westernized eating patterns with compositions that too much protein, fat, sugar, salt, and a little fiber. Other factors that contributed to is a fast-paced lifestyle and more sitting behind a desk so no more opportunities for physical activity or sport, the apparent result of wrong oneof her getting high numbers of the disease diabetes. It is need for active participation family to manage and help family members suffering from diabetes mellitus.

The family is the people closest often the accompanying sick family members, so that the role of the family is expected to increase the degree of health independently and continuously, including how in case management of patients DM. Current family support against the management of DM sufferers has not been optomal since knowledge and ability in helping families' members of his family. For it is necessary that effective information in order to meningktakan the role of the family in the management of the sufferers of the DM. The granting of very important information made through the family health education approaches at once became the basis of the need to do this research to prove whether there is effectiveness of health education of families against the management of diabetes mellitus in the working area Community Health Centre of Kalumata, City of Ternate.

\section{Statement of the Problem}

Prevalence of Diabetes Mellitus annually increasing that supposedly related to lifestyle changes (diet) along with increased prosperity and no longer limited to degenerative disease. Numerous attempts in the form of the study has been 


\section{International Journal of Science and Research (IJSR) \\ ISSN (Online): 2319-7064}

Index Copernicus Value (2016): 79.57 | Impact Factor (2015): 6.391

conducted to identify risk factors for Diabetes Mellitus, but the role of the family in managing family member with Diabetes Mellitus are not optimal. Yet its optimal role of the family was caused by lack of information about the management of people with Diabetes Mellitus which gleaned family, so the impact on the ignorance of the family in the management of the family member with Diabetes Mellitus. Thus, the problem of the research is "What was there education family health effectiveness against the management of Diabetes Mellitus patients after health education?"

\section{Research Method}

Design research is the overall plan of research to answer questions as well as the efforts of the anticipation of the difficulties that may arise in research (Sugiono, 2011). In this study using a Longitudinal Prospective design, i.e. "pre posttest control group design a non" where a certain treatment is done before the Group (X) given a pretest, then given treatment and conducted posttest after treatment or a measurement to find out the result of the treatment.

\section{Research on place and time}

a) The Place Of Research, Research carried out at the place of work-area Clinics Kalumta, City of Ternate, arguing in easy reach by researchers.

b) Research Time, Overall, this study was carried out for 5 months, starting in August until December 2017. and time of collecting data have been implemented starting on 04 November up to 02 December 2017.

\section{Population and Sample Research}

a) The population of the, The population of the region is a generalization of an object or subject that has certain qualities and characteristics set by the researchers to be studied and drawn the conclusion (Sugiyono, 2011). The population in this research is all families with family members suffering from diabetes mellitus.

b) Sample, The sample is part of the number and characteristics of which are owned by the population (Sugiyono, 2011). Sampling in this study using a nonprobability sampling approach with the method of purposive sampling, namely the dwarf sample assignment by selecting samples among the population in accordance with the desired researchers so that the sample can represent the characteristics of the population that has been known previously (Arikunto, 2008; Nursalam, 2011).

\section{Research Variables}

Research Variables are characteristics or conditions by the researchers manipulated, controlled or observed in a study that is divided into independent and independent variables (Sugiyono. 2011).

a) Independent Variable, That being the independent variable in this study is effectiveness of health education on the family.

b) The Dependent Variable, The dependent Variable or also called variable is the variable that is affected or which become due as a result of the free variable (Sugiyono,
2011). As for the dependent variable in this research is the management of diabetes mellitus patients include:
1) Food Planning
2) Physical Exercise
3) Maintenance of Foot
4) Hypoglycemic Drugs

\section{Result}

\section{Univariate Analysis}

Based on the results of the univariate analysis against the characteristics of respondents who obtained for status in the majority of families or children's status as dominated from clients of Diabetes Miletus i.e. as many as 16 respondents $(53.3 \%)$, for gender respondents who dominated the female gender is that is as much as 20 respondents $(66.7 \%)$, whereas for the ages obtained by respondents that dominates is aged a full Adult (Middle Years) that is as much as 21 respondents (70\%). For the educational level of respondents who dominated the educational level of respondents is the ADMIN, that is as much as 21 respondents (70\%), while for the type of work the respondents that dominates the other job is as much as 14 respondents (46.7\%), and for family income respondents every month that dominates is the respondents with revenues > us $\$ 1$ million by as much as 15 respondents $(50 \%)$.

Table 5.1: Distribution of respondents by virtue of family knowledge before giving educational attainment in the working area Clinics Kalumata city of Ternate of the year 2017

\begin{tabular}{|c|c|c|c|c|}
\hline Income & Frequency & Percent & Valid Percent & Cumulative Percent \\
\hline Good & 2 & 6.7 & 6.7 & 6.7 \\
\hline Enough & 10 & 33.3 & 33.3 & 40.0 \\
\hline Less & 18 & 60.0 & 60.0 & 100.0 \\
\hline Total & 30 & 100.0 & 100.0 & \\
\hline
\end{tabular}

The primary Data sources: 2017

Table 5.1 shows that knowledge of the family in the region of clinics Kalumata prior to health education, big was labeled an respondents or more dominant with knowledge less about diabetes mellitus, i.e. as many as 18 respondents (60\%).

Table 5.2: Distribution of respondents by virtue of family knowledge before giving educational attainment in the working area Clinics Kalumata Papers of the year 2017 \begin{tabular}{|l|l|l|l|l|}
\hline Income & Frequency & Percent & Valid Percent & Cumulative Percent \\
\hline
\end{tabular}

\begin{tabular}{|c|c|c|c|c|}
\hline Good & 18 & 60.0 & 60.0 & 60.0 \\
\hline Enough & 12 & 40.0 & 40.0 & 100.0 \\
\hline Total & 30 & 100.0 & 100.0 & \\
\hline
\end{tabular}

The primary Data sources: 2017

Table 5.2 shows the knowledge family in the region of clinics of Kalumata after do health education experience increasingly which is quite meaningful, as much of the 18 respondents $(60 \%)$ of the respondents have a good knowledge and no respondents who berpengethaun less about disease diabetes mellitus. 


\section{International Journal of Science and Research (IJSR) \\ ISSN (Online): 2319-7064}

Index Copernicus Value (2016): 79.57 | Impact Factor (2015): 6.391

Table 5.3: Distribution of management refers to respondents of Clients Diabetes Mellitus by the family before health

education at the working area of Kalumata Health Centre in

2017

\begin{tabular}{|c|c|c|c|c|}
\hline Income & Frequency & Percent & Valid Percent & Cumulative Percent \\
\hline
\end{tabular}

\begin{tabular}{|c|c|c|c|c|}
\hline Good & 8 & 26.7 & 26.7 & 26.7 \\
\hline Enough & 6 & 20.0 & 20.0 & 46.7 \\
\hline Less & 16 & 53.3 & 53.3 & 100.0 \\
\hline Total & 30 & 100.0 & 100.0 & \\
\hline
\end{tabular}

The primary Data sources: 2017

Table 5.3 shows the management of diabetes mellitus patients by family prior to health education most respondents barada in less category, i.e. as many as 16 respondents $(53.3 \%)$, the category is quite as much 6 the respondents (20\%), and as many as 8 respondents $(26.7 \%)$ who have good categories.

Table 5.4: Patient management based on distribution respondents of diabetes mellitus by family before health education at the working area of Kalumata Health Centre in 2017

\begin{tabular}{|l|l|l|l|l|}
\hline Income & Frequency & Percent & Valid Percent & Cumulative Percent \\
\hline
\end{tabular}

\begin{tabular}{|c|c|c|c|c|}
\hline Good & 19 & 63.3 & 63.3 & 63.3 \\
\hline Enough & 11 & 36.7 & 36.7 & 100.0 \\
\hline Total & 30 & 100.0 & 100.0 & \\
\hline
\end{tabular}

The primary Data sources: 2017

Table 5.4 shows the management of diabetes mellitus patients by health education after a family dominated by respondents categorized well, those as many as 19 respondents $(63.3 \%)$, and there are no respondents who have less in the category the management of diabetes mellitus clients.

\section{Bivariate Analysis}

Table 5.5: Who's Effectiveness in the management of diabetes mellitus patients' prior health education

\begin{tabular}{|c|c|c|c|c|c|}
\hline Model & \multicolumn{2}{|c|}{$\begin{array}{c}\text { Unstandardized } \\
\text { Coefficients }\end{array}$} & $\begin{array}{c}\text { Component } \\
\text { Coefficients }\end{array}$ & \multirow{2}{*}{ SIG. } \\
\cline { 2 - 4 } & B & Std Error. & Beta & & \\
\hline (Constant) & 1,442 & 661. & & 2,180 & 038. \\
\hline Pengetahuan1 & 326. & 254. & 236. & 1,284 & 410. \\
\hline
\end{tabular}

The primary Data sources: 2017

Table 5.5 shows the results of the statistical test ANOVA on the Pre Test Standard value obtained Coefficients Beta 0236, value $t$ with 1,284 Regression $p$ values 0410 . Then it can be concluded that there is no family health education effectiveness against the management of diabetes mellitus patient's prior health education with a value of significance $p$ value $<0.05$.

Table 5.6: Who's Effectiveness in the management of diabetes mellitus clients after health education

\begin{tabular}{|c|c|c|c|c|c|}
\hline Model & \multicolumn{2}{|c|}{$\begin{array}{c}\text { Unstandardized } \\
\text { Coefficients }\end{array}$} & $\begin{array}{c}\text { Component } \\
\text { Coefficients }\end{array}$ & \multirow{2}{*}{ SIG. } & \\
\cline { 2 - 4 } & $\mathrm{B}$ & Std Error. & Beta & & \\
\hline (Constant) & 472. & 210. & & 2,252 & 022. \\
\hline Pengetahuan1 & 639. & 141. & 649. & 4,520 & 000. \\
\hline
\end{tabular}

The primary Data sources: 2017
Table 5.6 shows the results of the statistical test ANOVA on the Posttest Standard value obtained Coefficients Beta 0649, $4,520 \mathrm{t}$ value with Regression $\mathrm{p}$ value 0000 . Then it can be inferred that there is family health education effectiveness against the management of diabetes mellitus patients after health education with a value of significance $p$ value $<0.05$.

Table 5.7: Difference in the effectiveness of health education of families against the management of Diabetes mellitus patients before and after health education

\begin{tabular}{|c|c|c|c|c|c|}
\hline Model & \multicolumn{2}{|c|}{$\begin{array}{c}\text { Unstandardized } \\
\text { Coefficients }\end{array}$} & $\begin{array}{c}\text { Component } \\
\text { Coefficients }\end{array}$ & t SIG. & \\
\cline { 2 - 5 } & $\mathrm{B}$ & Std Error. & Beta & & \\
\hline $\begin{array}{c}\text { Before health } \\
\text { education }\end{array}$ & 326. & 254. & 236. & 1,284 & 410. \\
\hline $\begin{array}{c}\text { After Health } \\
\text { Education }\end{array}$ & 639. & 141. & 649. & 4,520 & 000. \\
\hline
\end{tabular}

The primary Data sources: 2017

Table 5.7 shows the existence of a very meaningful difference between the effectiveness in the management of DM clients before and after health education is conducted, it is visible on before Regression test results conducted health education result $\mathrm{p}$ value 0410 , whereas when it is conducted health education is 0.000 . Then it can be inferred that there is a difference in the effectiveness of health education of patient management against family of diabetes mellitus before and after health education.

\section{Discussion}

The family is the closest person who often accompany sick family members, so the role of the family is expected to increase the degree of health independently and continuously, including how the role of the family in the management of patients diabetes mellitus. The results of this research show the status of the family in the management of patients of diabetes mellitus is dominated by the status of children that is as much as 16 respondents $(53.3 \%)$ of the 30 respondents. This means that the active role of families to manage their family members who suffered from diabetes mellitus becomes very important, as patients of diabetes mellitus generally experienced physical weakness and other complications.

According to Laili, n. R et all (2012), that the patients of diabetes mellitus often reveals symptoms of physical weakness so in need of another person or the nearest person (husband/wife/children) in conducting its activities. Other research also suggested that patients of diabetes mellitus commonly occur above 40 years old and often cause a variety of complications that affect the physical weakness and a zest for life. There are unisex which mention that diabetes mellitus patients aged above 45 years of age often have impaired circulation in the blood vessels. The problem or condition that requires the support of others, especially his wife and children/sumi (violet Gibbs Dyah, 2009; Sofiani, 2009).

The gender of the 30 respondents in research is dominated by the respondents are female-sex that is as much as 20 respondents $(66.7 \%)$. Indeed women are more at risk of

\section{Volume 6 Issue 12, December 2017}




\section{International Journal of Science and Research (IJSR) \\ ISSN (Online): 2319-7064}

Index Copernicus Value (2016): 79.57 | Impact Factor (2015): 6.391

having diabetes mellitus because women had the opportunity to physically increase in Body Mass Index. Monthly cycle syndrome (premenstrual Syndrome), Easter menopouse which makes the distribution of body fat is easy to accumulate due to the hormonal processes so that women at risk of suffering from diabetes mellitus. Related to this research mentioned that submission as a behavior where women have the instinct of compassion and concern greater than men, as well as more sensitive terhadapat of a problem include his family (health problems Wijaya, 2009; Prijadarminto, 2012).

The age of the respondents was dominated by the berusiadewa sa (Middle Years) between 39 - 49 years by as much as 21 respondents $(70 \%)$ of the 30 respondents. Similar results were also obtained from research conducted by Prameswari (2013) against 30 majority respondents aged 45 years > (Novelia, w. d., Sofiana, N, Oswati, h. 2014).

This is because those who have a high risk of diabetes are affected by who has a family history of diabetes, has entered the age of above 40 years old, overweight, high blood pressure, besides of course the wrong diet because of a change of style the life of the society and are usually in people this age are less active or exercising activity so the weight gain and muscle mass will decrease so that can lead to dysfunction of the pancreas. Besides the factors that can be modified are genetic factors as the originator of diabetes mellitus. The genes that are passed down from parent to child enlarge opportunities, if either parent has a history of diabetes mellitus then child (male or female) had a $25 \%$ have diabetes mellitus in the future. While if both parents have diabetes mellitus there rose to $75 \%$. In addition, $80 \%$ of the risk of diabetes mellitus are influenced by the environment (Soegondo, 2014).

Education is an important factor for any particular individual in order to understand and menegtahui the management of diabetes mellitus patients. The high level of education will have an impact on the knowledge of the patient's family. On the research of the level of education obtained 30 respondents most educated SLTA IE as much as 21 respondents (70\%). Similar results were also obtained in the research conducted by Kekenusa (2013) most respondents were high school graduates $(46.7 \%)$ Research by Lubis (2012) also showed the same results, namely the last level of education respondents percentage of HIGH SCHOOL graduates is/are all equal. The study concluded that the level of education can affect a person's behavior in applying knowledge of healthy living. The higher the level of education the higher one's knowledge in maintaining health or in other words the higher the level of education a person then the person is likely to behave positively (Sofiana, Novelia, Oswati, 2014). The types of jobs than 30 respondents in this research that dominates is the fixed memilikimpekerjaan not called work serabutan, that as many as 14 respondents (46.7\%). Earlier results also obtained a majority of respondents does not work or does not have a fixed activity i.e. as many as 14 people (46.7\%) of 30 responde (Novelia, Sofiana, Oswati, 2014).
Physical activities performed by people who are not working or only as housewife most likely less than people who have a job outdoors activities. Physical activity can increase insulin sensitivity and have an immediate effect against a decrease in blood glucose levels. Normal blood sugar levels tend to rise gradually after reaching the age of 40 years. To lower the blood sugar levels need to do physical activity such as exercise, because muscles use glucose contained in blood as energy (Black and Hawks, 2005, cited by Novelia, Sofiana, Oswati, 2014). Thus, the family should be able to know and understand the meaning and benefits of physical exercise or physical activity in order to decrease in blood sugar levels so that independently can play an active role in the management of diabetes mellitus patients.

\section{Family Knowledge before conducting health education}

The results of the analysis showed that knowledge prior to family health education most respondents have less knowledge, i.e. 18 respondents $(60 \%)$. This is certainly very impacting on the ability of families in the management of patients of DM. Research results it has in common with earlier research conducted by Rahmawati (2009) that most of the respondents which gymnastics diabetes already understand and understand about activities by a diabetic patients including there is the influence of health education with diabetic patient management capabilities against mellitus, evidenced by $69.9 \%$ of the respondents with high levels of knowledge.

\section{Management of the patients of diabetes mellitus health education prior to family}

The results showed that before carried out health education ability of families in the management of diabetes mellitus patients most respondents have less ability $(53.3 \%)$. Health education is for it to become one of the efforts to improve the knowledge and capabilities of the family in patient management DM. This is in accordance with the view of Notoatmojo (2010), that knowledge is a domain that is very important to the formation of the actions of a family, because of the experience and research it turns out that behavior based on the knowledge of more lasting from behaviour which is not based on knowledge.

\section{Management of the patients of diabetes mellitus se has do health education}

The results of the the research demonstrates the ability of the family in the management of diabetes mellitus patients after health education most respondents have kemmapuan well, that as many as 19 respondents (63.3\%). The ability of families in the management of diabetes mellitus patients after health education is much better. Increased ability of respondents is affected due to the prior posttest have been given health education through lectures and fast as well as using leaflets. Notoatmodjo (2010), stating that one of the advantages of leaflets is ease of understanding than by the methods of discussion or lecture and question and answer. 


\section{International Journal of Science and Research (IJSR) \\ ISSN (Online): 2319-7064}

Index Copernicus Value (2016): 79.57 | Impact Factor (2015): 6.391

Effectiveness of health education Health Education prior to family

An act or behavior committed by any individual or family will be more effective if it is based on adequate knowledge. Effectiveness of health education is one of the methods or ways to increase knowledge and ability in dealing with a family issue. According to Notoatmojo (2010), is the domain of knowledge that is essential for the formation of the actions of a family. Behavior based on knowledge will be more lasting than the behaviors that are not based on knowledge. It is very obvious connection with the research results, where the results of the statistical test ANOVA on the Pre Test Standard value obtained Coefficients Beta 0236, value $t$ with 1,284 Regression $p$ value 0410 . Then it can be inferred that there is no efektifitas health education family against management of clients of diabetes mellitus before do health education with a value of significance $p$ value $<0.05$.

\section{Effectiveness of health education family Se has conduct Health Education}

There is an increase in the ability of the family in the management of diabetic patients after health education. This can be proved by the results of the statistical test ANOVA on Post Test obtained the value of the Standard Beta Coefficients $0649,4,520 t$ value with Regression $p$ value 0000 . Then it can be inferred that there is family health education effectiveness against the management of diabetes mellitus patients after health education with a value of significance $p$ value $<0.05$. That means the better family health education undertaken increasingly effective role of the family in the management of diabetes mellitus patients. The results of this research are consistent with research conducted by Sukirjo (2010) that mention the education with the awarding of the leaflets is more effective than with no leaflets.

Family Health Education Effectiveness differences before and after Health Education carried out against the management of Diabetes mellitus Patients

The results of this study indicate there are the difference in the effectiveness of health education against the management of patient diabetes mellitus before and after health education. This is evidenced by the results of the test Regression before conducted health education obtained $p$ value 0410 , whereas when it is conducted health education was 0,000 . This means that the connection of the effectiveness of family health education towards management of patients diabetes mellitus at work-area Clinics Kalumata.

Health education is an activity or undertaking to deliver health messages to individuals, groups, and communities with the hope those individuals, groups, and the public can gain a better knowledge on health through the message, which in turn can affect behavior (Nurusalam, 2008; Notoatmodjo, 2013).

The liveliness of the family in the following health education indirectly have an impact on the results of the family know about managing diabetes mellitus, sources of information and mass media. By getting the right information, supported by the information submitted by doctors or other health care personnel on diabetes mellitus and its complications, is capable of supporting positive behavior of the family in the management of diabetes mellitus patients (Nurina, D.P. 2012). Family involvement in research is intended to improve family support against the management of diabetics' mellitus patients. One of the basic factors that can enhance the capabilities of supporting individual is family support (Orem, 2001).

The results of the previous research expressed support of influential families are means towards self-sufficiency level behavior of diabetes mellitus patients. Family involvement in the management of diabetes mellitus is very necessary because the family is the giver of care (caregiver) main for patients at home. Family environment could give a positive influence in the effort to live a healthy life behavior of diabetic patients. Families are expected to undertake the management of diabetic patients independently. As time goes by many diabetic patients experienced complications that impact physical weakness so that patients are not able to run its activities independently. In these conditions, the role of the family become very crucial in facilitating the patient run activity as expected (Nurina, DP, 2012; the image of Windani, p., Hartiah, h., Nursiswati, 2016).

In the process of health education of families in this study is run repeatedly and accompanied by follow-up and posttest. Diabetes Self-Management Education (DSME) recommends education family health must be done on an ongoing basis to provide the knowledge, skills, and abilities of the family in the management of patient's diabetes. This is corroborated by Dorresteijn et al. (2010) in Sofiana, Novelia, Oswati (2014), stating that education family health in the management of diabetic patients performed very effectively on an ongoing basis the occurrence of changes in the role of family. This is evident in the results of this study demonstrated the effectiveness of family health education towards the management of diabetes mellitus patients after health education. This means that there is a difference in the effectiveness of health education of families against the management of diabetes mellitus patients before and after health education.

\section{Conclusions and Suggestions}

The result of this study can conclude that:

1. There are no family health education effectiveness against the management of diabetes mellitus patients prior health education with the value of the Regression $(p$ value $=0410)$.

2. There are family health education effectiveness against the management of diabetes mellitus patients after health education with value Regression $p$ value $=0000$.

3. There is a difference in the effectiveness of health family education against management of the patients of diabetes mellitus before and after health education with value Regression $p$ value $=0000$.

Furthermore the suggestions based on the research are:

1) Further research is needed on managing diabetes mellitus patients with a specific food planning, physical exercise, 


\section{International Journal of Science and Research (IJSR) \\ ISSN (Online): 2319-7064}

Index Copernicus Value (2016): 79.57 | Impact Factor (2015): 6.391

maintenance and working area in hypoglycemic drug Clinics Kalumata Papers.

2) Required of planning of the development and improvement of the quality of nursing in the integral resources through improved education and training expertise, particularly for the nurse manager DM.

3) Need for efforts to improve interpersonal skills for family members of people with diabetes with assertive and build a relationship of cooperation that are conducive intercultural nurse with the patient's family in the management of diabetes mellitus.

\section{References}

[1] Arikunto, (2008). Prosedur Penelitian Suatu Pendekatan Praktek, Edisi Revisi, Rineka Cipta, Jakarta.

[2] (2011). Metode Penelitian Kuantitatif, Kualitatif dan $R \& D$. Alfabeta: Bandung

[3] Citra Windani, MS, Hartiah, H., Nursiswati (2016).Pengaruh Program Edukasi Perawatan Kaki Berbasis Keluarga terhadap Perilaku Perawatan Kaki pada Pasien Diabetes Melitus Tipe 2 https://ejurnal.poltekkestjk.ac.id/index.php/JKEP/article/ view/576, diakses tgl 11 Desember 2017

[4] Kemenkes RI. (2015). Rencana Strategis Kementerian Kesehatan Tahun 2015-2019. Kemenkes RI. Jakarta

[5] Laili N.R et all (2012), Edukasi Dengan Pendekatan Prinsip Diabetes Self Management Education (DMSE) Meningkatkan Perilaku Kepatuhan Diet Pada Penderita Diabetes Melitus Tipe 2. https://ejurnal.poltekkestjk.ac.id/ index.php/JKEP/article/view/576. diakses tanggal 5 Desember 2017

[6] Malilyn M. Fridman, (2008). Keperawatan Keluarga Teori dan Praktik, Edisi 3. EGC, Jakarta.

[7] Mappiane Andi AT, (2012), Pengantar Konseling \& Psikoterapi, Cet. 3. Edisi I. Rajawali Press Citra Niaga Buku perguruan Tinggi Jakarta.

[8] Merry. E Beck, (2003). Nutrition and Dietetics for Nurses, Yayasan Esentia Medica, Yogyakarta.

[9] Niven Neil (2002), Psikologi Kesehatan, Cetakan I, Jakarta., EGC.

[10] Nevid, J.S., Rathus S. A. \& Green B. (2005). Psikologi Abnormal. Edisi kelima, Jilid Dua. Erlangga: Jakarta

[11] Noer. Syaifoellah, (2001). Buku Ajar Ilmu Penyakit Dalam. jilid I. Edisi 3. Balai Penerbit FK UI, Jakarta.

[12] Notoatmodjo, S (2007). Prinsip-prinsip Dasar Ilmu Kesehatan Masyarakat. Cetakan 2, Rineka Cipta. Jakarta.

[13] ,(2013). Promosi Kesehatan dan Ilmu Perilaku, Rineka Cipta, Jakarta

[14] , (2015). Pengantar Ilmu Kesehatan dan Ilmu Perilaku, Andi Offset Yogyakarta.

[15] Novelia, Sofiana, Oswati (2014). Pengaruh pendidikan kesehatan senam kaki melalui media audio visual terhadap pengetahuan pelaksanaan senam kaki Pada pasien DM tipe 2.

[16] https://scholar.google.co.id/scholar?q=Efektifitas+Pendi dikan+kesehatan+terhadap+pengelolaan+diabetes+melit us\&hl=id\&as_sdt=0\&as_vis=1\&oi=scholart\&sa=X\&ved
=0ahUKEwjXtP7xYXYAhUJOo8KHfxqAEoQgQMIJz

AA.diakses tanggal 13 Desember 2017

[17] Nurina, DP. (2012). Hubungan Dukungan Pasangan Dan Health Locus Of Control Dengan Kepatuhan Dalam Menjalani Proses Pengobatan Pada Penderita Diabetes Mellitus Tipe-2.

[18] https://journal.ubaya.ac.id/index.php/jimus/article/view/6 9/49 diakses tanggal 13 Desember 2017

[19] Nursalam dan Efendi Ferry (2008), Pendidikan Dalam Keperawatan, Salemba Medika. Jakarta.

[20] Nursalam. (2011). Konsep dan penerapan metodologi penelitian ilmu keperawatan: Pedoman skripsi, tesis dan instrumen penelitian keperawatan (Edisi kedua). Salemba Medika: Jakarta

[21] Pranadji, D.K.V, Martianto, D.H, Subandriyo, V.U, (2011). Perencanaan menu untuk penderita diabetes mellitus, cetakan 4. Penebar Swadaya, Jakarta

[22] Prijadarminto (2012), Kepatuhan Sebagai Suatu Perilaku, Jakarta. CV Balai Pustaka

[23].Purnamasari Dyah (2009), Buku Ajar Ilmu Penyakit Dalam, Edisi 5, Jakarta. Interna Publishing.

[24] Purwanto Nasrul. H (2011), Hubungan Pengetahuan Tentang Diet Diabetes Melitus Dengan Kepatuhan Pelaksanaan Diet Pada Penderita Diabetes Melitus. Jurnal Keperawatan, 01(01)

[25] Setiawan Dalimartha, (2008). Ramuan Tradisional Untuk Pengobatan Diabetes Mellitus, Penebar Swadayu, Jakarta

[26] Sastro Asmoro. S dan Ismail, (2005). Dasar-dasar Methodologi Penelitian Klinik, Bina Rupa Aksara, Jakarta.

[27] Sugiyono, (2011). Statistik Nonparametris Untuk Penelitian, Edisi 3. CV. ALFABETA Bandung.

[28] (2011). Metode penelitian kuantitatif kualitatif dan R \& D. Alfabeta : Bandung.

[29] Soegondo Sidartawan (2014), Diabetes The Silent Killer.www.medicarestore.com, diakses tanggal 28 Nivember 2017

[30] Sulita dkk, (2011). Pendidikan Kesehatan dalam Keperawatan. EGC. Jakarta

[31] Suprajitno. (2004). Asuhan keperawatan keluarga: Aplikasi dalam praktik. EGC: Jakarta

[32] Sofiani, Y.(2009).Analisis Hubungan dan Budaya Pasien diabetes Melitus Yang Mengalami Amputasi Kaki Dengan Kualitas Hidup Dalam Konteks asuhan Keperawatan Pasien Diabetis Melitus Di DKI Jakarta . Jurnal Kedokteran dan Kesehatan, 5 (2), 123- 133. diakses tgl 09 Desember 2017

[33] Tjiptono, Chandra, Diana, 2004. Marketing Scale. Penerbit ANDI. Yogyakarta

[34] Tjokroprawiro. Askandar, (2009). Diabetes Mellitus Klasifikasi, Diagnosa dan Terapi, Edisi 4, Pt Gramedia Pustaka Utama, Jakarta.

[35] Wijaya Anton Cahaya (2009), Wanita Lebih Beresiko (1), www.nova.com,http:// www.tabloi dnova.com/Nova/Kesehatan/ Wanita/aWanitaLebihBeresiko-1. diakses tanggal 28 November 2017.

\section{Volume 6 Issue 12, December 2017}

